\title{
Article \\ Nutritional Health Education in Pregnant Women in a Rural Health Centre: Results in Spanish and Foreign Women
}

\author{
Mercedes de Dios-Aguado ${ }^{1,2}{ }^{(D}$, María Teresa Agulló-Ortuño ${ }^{3}$, María Idoia Ugarte-Gurrutxaga ${ }^{2,3}$ (D), \\ Benito Yañez-Araque ${ }^{4}$ (D) Brigida Molina-Gallego ${ }^{2,3}$ and Sagrario Gómez-Cantarino ${ }^{2,3,5, *(\mathbb{D})}$ \\ 1 Primary Health Care No.1. Health Centre, Yepes, Castilla-La Mancha Public Health Service (SESCAM), \\ 45005 Toledo, Spain; mded@sescam.jccm.es \\ 2 Research Group Nursing, Pain and Care (ENDOCU), UCLM, Av. Carlos III s/n, 45071 Toledo, Spain; \\ Maria.Ugarte@uclm.es (M.I.U.-G.); brigida.molina@uclm.es (B.M.-G.) \\ 3 Faculty of Physiotherapy and Nursing of the Toledo Campus, University of Castilla-La Mancha (UCLM), \\ 45071 Toledo, Spain; mariateresa.agullo@uclm.es \\ 4 Department of Physical Activity and Sports Sciences, Campus Toledo, University of Castilla-La Mancha, \\ 45071 Toledo, Spain; benito.yanez@uclm.es \\ 5 Health Sciences Research Unit: Nursing (UICISA: E), Coimbra School of Nursing (ESEnfC), \\ 3004-011 Coimbra, Portugal \\ * Correspondence: sagrario.gomez@uclm.es; Tel.: +34-925-268-800 (ext. 5800)
}

Citation: Dios-Aguado, M.d.; Agulló-Ortuño, M.T.; Ugarte-Gurrutxaga, M.I.; Yañez-Araque, B.; Molina-Gallego, B.; Gómez-Cantarino, S. Nutritional Health Education in Pregnant Women in a Rural Health Centre: Results in Spanish and Foreign Women. Healthcare 2021, 9, 1293. https:// doi.org/10.3390/healthcare9101293

Academic Editor:

Marzena Jeżewska-Zychowicz

Received: 24 July 2021

Accepted: 22 September 2021

Published: 29 September 2021

Publisher's Note: MDPI stays neutral with regard to jurisdictional claims in published maps and institutional affiliations.

Copyright: (c) 2021 by the authors. Licensee MDPI, Basel, Switzerland. This article is an open access article distributed under the terms and conditions of the Creative Commons Attribution (CC BY) license (https:// creativecommons.org/licenses/by/ $4.0 /)$.

\begin{abstract}
The dietary behaviour of pregnant women, as well as the socio-cultural conditions in which pregnancy takes place, influence obstetric outcomes. To analyse the influence of socioeconomic factors and dietary habits on obstetric outcomes in Spanish and foreign pregnant women living in a rural environment, a population-based, prospective-observational study in a cohort of Spanish and foreign pregnant women in the town of Yepes, in the province of Toledo, Spain was conducted. Foreign pregnant women are ecodependent on their partners, have secondary education and low socioeconomic level. Spanish pregnant women have secondary education, a medium socio-economic level, live with their partners and are economically independent. Moreover, $85 \%$ of Spanish pregnant women gave birth at term and reached a gestational age of $40 \pm 1.83$ weeks. However, only $55 \%$ of foreign pregnant women reached a gestational age of $39.72 \pm 2.28$ weeks. Through health education, pregnant women in this geographical area of Castilla la Mancha, Spain, adopted bicultural dietary patterns, thus reaching the prescribed diet of $2000 \mathrm{Kcal}$. Through this diet, both Spanish and foreign pregnant women maintained albumin and plasma protein levels within the established range, with no significant differences in obstetric outcomes among pregnant women in the study.
\end{abstract}

Keywords: health; education; lifestyle; beliefs; risk factors; pregnancy outcome; foreign and Spanish pregnant women

\section{Introduction}

The development of a new life causes changes in the mother's physiology and psyche throughout pregnancy, resulting in an increased demand for nutrients [1]. Pregnant women can physiologically increase their blood volume by up to $40-45 \%$, resulting in a $25 \%$ decrease in serum protein and albumin concentrations [2]. This fact, together with the increase in protein requirements from the second month of gestation due to the growth of maternal and foetal tissues, obliges women to eat a balanced diet that favours placental quality and achieves optimal intrauterine foetal development. Protein accounts for 15-25\% of the total caloric intake of a pregnant woman's diet [3]. To maintain an optimal protein range, pregnant women should receive health education on the consumption of protein-rich foods, such as eggs, milk and dairy products, meat and legumes $[4,5]$.

Applying current protocols and carrying out adequate nutritional education for optimal maternal and foetal development during pregnancy contributes to the achievement of a healthy eating culture in pregnant women. In this way, health professionals who care 
for women during pregnancy should promote HE from the first visit, focusing on healthy eating habits and lifestyles, mainly those that are unknown and/or harmful to the pregnant woman. Thus, in each trimester, the pregnant woman undergoes a check-up in which her anthropometric measurements are controlled and a blood test is performed to check the serological values of glucose, total protein and albumin, the latter indicators of nutritional quality [6-9].

In this regard, the International Federation of Gynaecology and Obstetrics, as well as the National Health Systems of several countries [7-9], have developed manuals that clearly explain the recommendations on the quantity and quality of food that women should eat during pregnancy, with the intention of maintaining adequate weight gain at this stage of their lives [6-10].

Nowadays, the lifestyle of the population is influenced by the media, cultural and socioeconomic factors. Therefore, the lifestyle of the pregnant woman is influenced by these circumstances as well as her family environment [11]. In this sense, following the conceptual framework of socioeconomic determinants of social inequalities in health, which specifically for foreign women are gender, ethnicity and territory, which together result in language barriers, less economic independence and job insecurity [12]. Thus, foreign pregnant women are more likely to have an inadequate diet. At the same time, Spanish pregnant women, despite being aware of the benefits of a Mediterranean diet, do not always follow it. This situation should be considered by the health professionals involved in HE from the beginning of the gestational period and continuing throughout the three trimesters of pregnancy. This situation will allow the pregnant woman to acquire adequate nutritional habits during her pregnancy, which will benefit the different members of the family unit. This will facilitate a diet in accordance with nutritional needs during the different stages of life [1-3]. HE should be carried out with the aim of reinforcing an adequate diet during pregnancy and achieving optimal obstetric outcomes [3,11,13-17].

The aim of this research is to describe the influence of socioeconomic factors and dietary behaviours on the obstetric outcomes of Spanish and foreign pregnant women living in a rural environment, specifically in the town of Yepes, in the province of Toledo, Spain.

\section{Materials and Methods}

\subsection{Study Design and Participants}

This is prospective observational population-based research conducted in the period from January 2019 to March 2020. The selected sample is pregnant women residing in a rural geographical area of the Community of Castilla La Mancha (Yepes, Toledo, Spain). In this rural area in 2020, according to the municipal census, there were 2570 women, of whom 1040 were of childbearing age (15-45 years), of whom 843 were Spanish and 197 foreign.

The overall research sample is composed of a total of 194 women who were attended throughout their pregnancy in the rural Public Health Centre of Yepes (Toledo). The sample is divided into two groups: (1) pregnant women of Spanish nationality comprising 121 women; (2) pregnant women of foreign nationality comprising 73 women. Inclusion criteria were women over 18 years of age, with a singleton pregnancy, with knowledge of Spanish, English or French and who voluntarily agreed to participate in the study. Exclusion criteria were women with pregestational pathologies, such as hypertension, preeclampsia in previous pregnancies or gestational diabetes.

During the scheduled visits to the Health Centre, all women answered questions (anamnesis) asked by the professionals about their obstetric history, socioeconomic status and dietary habits. During the three trimesters of pregnancy, women had their anthropometric measurements taken on the same scales and scalimeter, and analytical tests were also carried out in the same laboratory. All pregnant women were provided with the 2000 Kcalorie diet implemented by the Obstetrics Service of the Complejo Hospitalario Universitario de Toledo (CHUT).

Information on pregnancy outcomes (type of delivery, hours of duration, birth weight of the newborn) was obtained from the medical records of each patient. 


\subsection{Evaluation of Biochemical Parameters in Blood}

Blood samples were taken at each of the scheduled visits for the pregnant women so that determinations were made in the first trimester (T1; between 6 and 9 weeks of gestation), second trimester (T2; 26 weeks of gestation), and third trimester (T3; 35 weeks of gestation).

The blood samples were obtained by venous puncture of the forearm with EDTA collection tubes, immediately centrifuged and transported to the central laboratory for analysis. Metabolites were quantified by commercial enzymatic and standard chemistry methods on an ADVIA ${ }^{\circledR} 2400$ Automated Clinical Chemistry System (Bayer Healthcare LL; Whippany, NJ, USA). The reference ranges established in the laboratory are $6.4-8.3 \mathrm{~g} / \mathrm{dL}$ for total plasma protein, $3.4-4.8 \mathrm{~g} / \mathrm{dL}$ for plasma albumin, and $70-100 \mathrm{mg} / \mathrm{dL}$ for plasma glucose.

The serum parameters of total protein and albumin were chosen for analysis in this study because they are indicators of the nutritional quality of the woman's diet. In addition, glucose was chosen because it is a recommended indicator in the CHUT Obstetrics Service protocol.

\subsection{Statistical Analysis}

The collected data were all quantitative and the IBM SPSS Statistics 25 software (IBM, Armonk, NY, USA) was used for data analysis. After data collection, the data were transferred to SPSS to create the database needed for the analyses. Once the database was created, those cases that did not meet the previously defined requirements to belong to each population sample were eliminated.

Subsequently, the scores of each subject in the two groups were calculated. Statistics of median, mean, standard deviation (SD) or interquartile range (IR) were used to describe the parameters used. Differences in parameter distributions between the two groups of patients studied were analyzed using Student's $t$-tests, ANOVA, or Mann-Whitney U test if the distribution deviated from normality. For categorical data, the chi-square test was used and relationships between variables were established with Pearson or Spearman correlation coefficients. All tests were two-tailed and a $p<0.05$ was considered significant.

\subsection{Ethical Consideration}

This study has been conducted to the highest ethical standards, in accordance with the Declaration of Helsinki, International Conference on Harmonization Guidelines for Good Clinical Practice, and national ethical and legal requirements. All women included in this study signed an informed consent form prior to their inclusion in the study. The Clinical and Research Ethics Committee of the Toledo Hospital Complex approved the objectives and procedures of this study.

\section{Results}

This section may be divided into subheadings. It should provide a concise and precise description of the experimental results, their interpretation, as well as the experimental conclusions that can be drawn.

\subsection{Socioeconomic Characteristics of the Women Included in the Study}

The sample of 194 pregnant women was divided into two groups, with 121 women belonging to the group of Spanish pregnant women and 73 women belonging to the group of foreign pregnant women.

The socio-economic status variable, which combines income, education and employment, can be correlated with the socio-economic status given by the National Statistics Institute (INE), which relates annual household income and average income per consumption unit, which in the case of the municipality of Yepes, was EUR 16,908 per person [18]. Thus, the women in the research can be classified into four categories of socio-economic status: Low, Medium, Medium-high and High. Table 1 shows that $47.9 \%$ of Spanish women 
are in the medium socio-economic level, while $56.2 \%$ of foreign women are in the low socio-economic level.

Table 1. Socioeconomic characteristics of 194 women included in the study.

\begin{tabular}{cccc}
\hline N & $\begin{array}{c}\text { Spanish } \\
\mathbf{1 2 1}\end{array}$ & $\begin{array}{c}\text { Foreign } \\
\mathbf{7 3}\end{array}$ & $p$ \\
\hline $\begin{array}{c}\text { Socio-economic level according to average } \\
\text { disposable income }(N, \%)\end{array}$ & & \\
Low $(<70 \%)$ & $21(17.4)$ & $41(56.2)$ & $<0.001^{2}$ \\
Medium (70-125\%) & $58(47.9)$ & $23(31.5)$ & \\
Medium-high (125-200) & $26(21.5)$ & $6(8.2)$ & \\
High (>200\%) & $16(13.2)$ & $3(4.1)$ & \\
\hline Economic dependence $(N, \%)$ & & & \\
Independent (woman with own salary) & $66(55.5)$ & $18(24.7)$ & \\
Dependent (woman without a salary) & $53(44.5)$ & $55(75.3)$ & \\
\hline Education level (N, \%) & & & \\
Illiterate & 0 & $3(4.1)$ & \\
Primary School & $32(26.4)$ & $21(28.8)$ & \\
Secondary School & $66(54.5)$ & $41(56.2)$ & \\
Bachelor or higher & $23(19.0)$ & $8(11.0)$ & $0.6401^{2}$ \\
\hline Maternal age (years) mean \pm SD & $30.88 \pm 5.88$ & $30.47 \pm 5.94$ & \\
\hline Live as a couple & & & \\
Yes & $114(94.2)$ & $70(95.9)$ & $3(4.1)$ \\
No & $7(5.8)$ & & \\
\hline
\end{tabular}

Mean \pm or frequency (\%) values are shown. ${ }^{1} t$-Student test. ${ }^{2}$ Chi-square test.

Therefore, the study variables socio-economic level and economic dependence between Spanish and foreign women show a significant statistical difference as $p=<0.001$.

In this sense, it is shown that $24.7 \%$ of foreign pregnant women are economically independent, compared to $55.5 \%$ of Spanish pregnant women. Therefore, this variable shows a significant difference between both groups of pregnant women, since $p=<0.001$.

Likewise, there are no significant differences related to their level of education, since $54.5 \%$ of Spanish women have secondary education compared to $56.2 \%$ of foreign women and $11.0 \%$ of foreign pregnant women have university studies compared to $19 \%$ of Spanish women.

The average age of Spanish pregnant women is 30.88 years, while in the group of foreign pregnant women it is 30.47 years, so this variable does not show significant differences.

\subsection{Pregnant Women's Dietary Behaviour}

To address this point, it is necessary to consider that the 73 foreign pregnant women included 7 Romanians, 3 Bulgarians, 25 Moroccans, 14 Algerians, 4 Tunisians, 2 Chinese, 2 Syrians, 6 Bolivians, 6 Peruvians, 2 Argentinians, 1 Colombian and 1 Mexican.

During the first visit with the primary care nurse, the nutrition of the pregnant women in both groups was verified.

Subsequently, the 2000 Kcalorie diet implemented by the CHT Obstetrics Service and the minimum portions to be consumed from each of the food groups were given and explained, adapting them to their beliefs, culinary habits, religion and culture (Table 2).

Adherence to the diet was checked during subsequent visits scheduled for the second and third trimesters.

It is observed that in both groups of pregnant women, between the second and third trimester of gestation, there are positive changes in diet, with an increase in the consumption of dairy products, cereals, pulses, vegetables and fruit. At the same time, there was an increase in the consumption of eggs in both groups. 
Table 2. Nutritional habits of 194 women included in the study.

\begin{tabular}{cccccc}
\hline \multirow{2}{*}{ Type of Aliments } & $\begin{array}{c}\text { Recommended } \\
\text { Servings }\end{array}$ & \multicolumn{2}{c}{$\begin{array}{c}\text { Consume Recommended } \\
\text { Amounts in T2 (N, \%) }\end{array}$} & \multicolumn{2}{c}{$\begin{array}{c}\text { Consume Recommended } \\
\text { Amounts in T3 (N, \%) }\end{array}$} \\
\cline { 2 - 6 } & 7 & Spanish & Foreign & Spanish & Foreign \\
\hline Cereal & 7 & $85(70.8)$ & $55(75.3)$ & $103(85.12)$ & $70(95.89)$ \\
\hline Pulse & 4 & $77(63.63)$ & $47(64.38)$ & $116(95.86)$ & $71(97.26)$ \\
\hline Vegetables & 3 & $68(56.2)$ & $42(57.53)$ & $108(89.25)$ & $72(98.63)$ \\
\hline Fruits & 3 & $32(26.44)$ & $19(26.02)$ & $43(35.53)$ & $23(31.5)$ \\
\hline Dairy products & 3 & $63(52.06)$ & $37(50.68)$ & $74(61.15)$ & $37(50.68)$ \\
\hline Meats & 3 & $55(45.45)$ & $33(45.2)$ & $67(55.37)$ & $33(45.2)$ \\
\hline Fish & 2 & $21(17.35)$ & $15(20.54)$ & $33(27.27)$ & $30(41)$ \\
\hline Eggs & 1 & $90(74.38)$ & $53(72.6)$ & $53(43.8)$ & $37(50.68)$ \\
\hline $\begin{array}{c}\text { Pre-cooked meals } \\
\text { and pastries }\end{array}$ & & & & &
\end{tabular}

However, the consumption of meat and fish increased in the group of Spanish pregnant women and no significant changes were found in the group of foreign pregnant women. It should be noted that in both groups there was a decrease in the consumption of precooked food and pastries. This is related to receiving health education and high motivation for change on the part of the pregnant women.

\subsection{Biochemical Parameters of the Women Included in the Study}

Total plasma protein concentration decreased progressively throughout the three trimesters of pregnancy in all women in our cohort. However, we observed statistically significant differences in these levels throughout pregnancy between Spanish and immigrant women (Table 3), with immigrant women maintaining higher protein levels. This is similar with respect to plasma albumin levels, although there are no statistically significant differences between the two population groups.

Table 3. Biochemical parameters in pregnant women included in the study.

\begin{tabular}{cccc}
\hline & Spanish & Foreign & $p$-Value ${ }^{\mathbf{1}}$ \\
\hline Total protein (mean $\pm \mathrm{SD})(\mathrm{g} / \mathrm{dL})$ & & & \\
T1 & $7.00 \pm 0.37$ & $7.25 \pm 0.41$ & $<0.001$ \\
T2 & $6.48 \pm 0.35$ & $6.64 \pm 0.39$ & 0.003 \\
T3 & $6.23 \pm 0.45$ & $6.47 \pm 0.37$ & $<0.001$ \\
\hline Albumin (mean $\pm \mathrm{SD})(\mathrm{g} / \mathrm{dL})$ & & & \\
T1 & $4.43 \pm 0.31$ & $4.49 \pm 0.28$ & 0.175 \\
T2 & $3.88 \pm 0.32$ & $3.94 \pm 0.27$ & 0.19 \\
T3 & $3.69 \pm 0.40$ & $3.72 \pm 0.22$ & 0.5 \\
\hline Glucose (mean \pm SD) (mg/dL) & & & \\
T2 & $81.49 \pm 8.64$ & $81.66 \pm 8.58$ & 0.894 \\
T3 & $81.59 \pm 9.86$ & $81.66 \pm 6.46$ & 0.954 \\
\hline
\end{tabular}

Legends: T1: first trimester; T2: second trimester, and T3: third trimester of pregnancy. ${ }^{1} t$-Student test.

With respect to plasma glucose measurements, none of the women included in this study had values indicative of gestational diabetes. However, the glucose levels of the immigrant women were slightly higher than those of the Spanish women. This was statistically significant in the third trimester $(p=0.042$, Table 3$)$.

\subsection{Anthropometric Characteristics and Obstetric Data of the Women Included in the Study}

In the study, at the beginning of pregnancy, women in the foreign group had a higher pregestational weight than women in the Spanish group. However, this difference 
was not found at the end of pregnancy, with a similar BMI between both population groups. Only $4.12 \%$ of pregnant women were underweight at the beginning of pregnancy $\left(\mathrm{BMI}<18.5 \mathrm{~kg} / \mathrm{m}^{2}\right)$, and all of them were of Spanish nationality. In contrast, $41.24 \%$ of the women started their pregnancy overweight (BMI $\left.>25 \mathrm{~kg} / \mathrm{m}^{2}\right)$, of whom 44 were Spanish and 36 were of foreign nationality (2 Romanian, 12 Moroccan, 6 Bolivian, 4 Peruvian, 6 Algerian, 2 Tunisian, 2 Argentinean, 1 Bulgarian and 1 Mexican) (Table 4).

Table 4. Anthropometric characteristics and obstetric data of women included in the study.

\begin{tabular}{|c|c|c|c|}
\hline & Spanish & Foreign & $p$-Value \\
\hline $\begin{array}{c}\text { Height (m) } \\
\text { Median [IR: Q3, Q1] }\end{array}$ & $\begin{array}{c}1.61 \\
{[1.58,1.66]}\end{array}$ & $\begin{array}{c}1.62 \\
{[1.58,1.68]}\end{array}$ & $0.2682^{1}$ \\
\hline $\begin{array}{l}\text { Weight at T1 }(\mathrm{Kg}) \\
\text { Median [IR: Q3, Q1] }\end{array}$ & $\begin{array}{c}62 \\
{[54.7,71.75]}\end{array}$ & $\begin{array}{c}68 \\
{[60.0,73.0]}\end{array}$ & $0.0262^{1}$ \\
\hline $\begin{array}{l}\text { Weight at T3 }(\mathrm{Kg}) \\
\text { Median [IR: Q3, Q1] }\end{array}$ & $\begin{array}{c}71.5 \\
{[63.00,82.75]}\end{array}$ & $\begin{array}{c}73.5 \\
{[68.00,72.25]}\end{array}$ & $0.1052^{1}$ \\
\hline $\begin{array}{l}\text { BMI at T1 }\left(\mathrm{Kg} / \mathrm{m}^{2}\right) \\
\text { Median [IR: Q3, Q1 }\end{array}$ & $\begin{array}{c}23.99 \\
{[20.66,27.17]}\end{array}$ & $\begin{array}{c}25.05 \\
{[22.24,27.47]}\end{array}$ & $0.0842^{1}$ \\
\hline $\begin{array}{l}\text { BMI at T3 }\left(\mathrm{Kg} / \mathrm{m}^{2}\right) \\
\text { Median [IR: Q3, Q1] }\end{array}$ & $\begin{array}{c}27.41 \\
{[24.03,30.71]}\end{array}$ & $\begin{array}{c}27.14 \\
{[25.00,29.62]}\end{array}$ & $0.7412^{1}$ \\
\hline $\begin{array}{l}\text { Weight gain T1-T3 }(\mathrm{Kg}) \\
\quad(\text { mean } \pm \mathrm{SD})\end{array}$ & $9.43 \pm 4.20$ & $8.42 \pm 4.18$ & $0.1093^{2}$ \\
\hline $\begin{array}{c}\text { Type of Birth }(N, \%) \\
\text { Eutocic } \\
\text { Instrumental } \\
\text { Caesarean }\end{array}$ & $\begin{array}{l}85(70.8) \\
12(10.0) \\
23(19.2)\end{array}$ & $\begin{aligned} 55 & (77.5) \\
5 & (7.0) \\
11 & (15.5)\end{aligned}$ & $0.5934^{3}$ \\
\hline $\begin{array}{l}\text { Newborn weight }(\mathrm{Kg}) \\
\text { Median [IR: Q3, Q1] }\end{array}$ & $\begin{array}{c}3.4 \\
{[3.03,3.61]}\end{array}$ & $\begin{array}{c}3.19 \\
{[3.00,3.55]}\end{array}$ & $0.3612^{1}$ \\
\hline
\end{tabular}

T1: first trimester of pregnancy, T3: third trimester of pregnancy. BMI: Body Mass Index; IR: Interquartile range Mann-Whitney $\mathrm{U},{ }^{1}$ Student's $t$-test, ${ }^{2}$ Chi-square, ${ }^{3}$ test.

The mean height of the Spanish pregnant women was $1.62 \mathrm{~m}$ and $1.63 \mathrm{~m}$ for the foreign pregnant women. Relating the type of delivery to this variable, it was observed that $19.2 \%$ of Spanish pregnant women had a caesarean delivery, mainly associated with women with a height of $1.58 \mathrm{~m}$, being lower in the group of foreign women $(15.5 \%)$ with an average height of $1.60 \mathrm{~m}$.

As shown in Table 5, there is a correlation between the weight of the baby and the height of the mother, since the shorter the mother, the greater the probability of caesarean delivery, a fact that is true in the group of Spanish pregnant women.

Table 5. Relationship between maternal height, birth weight and weeks of gestation.

\begin{tabular}{cccccccc}
\hline Type of Delivery & \multicolumn{2}{c}{ Height of Mother $(\mathbf{m})$} & \multicolumn{2}{c}{ Baby's Weight $(\mathbf{K g})$} & \multicolumn{2}{c}{ Week of Gestation } \\
\hline & Spanish & Foreign & Spanish & Foreign & \multicolumn{2}{c}{ Spanish } & Foreign \\
\hline Euthocic & $1.625 \pm 0.053$ & $1.634 \pm 0.071$ & $3.309 \pm 0.440$ & $3.407 \pm 0.477$ & $39.92 \pm 1.79$ & $40.25 \pm 0.93$ \\
\hline Instrumental & $1.628 \pm 0.063$ & $1.630 \pm 0.071$ & $3.196 \pm 0.576$ & $2.625 \pm 0.991$ & $40.17 \pm 0.94$ & $36.40 \pm 4.93$ \\
\hline Caesarean section & $1.588 \pm 0.051$ & $1.600 \pm 0.058$ & $3.413 \pm 0.465$ & $2.911 \pm 0.968$ & $40.61 \pm 1.23$ & $38.55 \pm 3.75$ \\
\hline
\end{tabular}

In general, Spanish women had a mean gestation time of $40 \pm 1.83$ weeks, while the gestation time of foreign women was $39.72 \pm 2.28$ weeks. Moreover, Spanish women had more post-term pregnancies ( $>41$ weeks gestation) than foreign women, while the latter had more preterm deliveries ( $<37$ weeks gestation). 
It is noteworthy that of the six women in the study who had preterm births, four corresponded to the group of foreign pregnant women. In addition, the data detailed in Table 4 reveal that foreign women had a higher number of instrumental or caesarean deliveries due to preterm pregnancies.

\section{Discussion}

This paper studies a cohort of Spanish and foreign pregnant women who followed their pregnancy at the Yepes Primary Care Centre, located in a rural area of the province of Toledo (Spain). The women followed the pregnancy protocol established by the obstetrics unit of the Castilla-La Mancha Health Service (SESCAM), on which the Yepes Health Centre depends.

The health professional's supervision of the women during the three trimesters of gestation in relation to their state of health, analytical parameters and adherence to the $2000 \mathrm{kcal}$ protocolised diet has resulted in the women achieving full-term deliveries and healthy newborns regardless of the culture or country of origin of the pregnant woman.

The gestational age of the sample in this study is in line with what the Spanish Society of Gynaecology and Obstetrics highlights as most likely to be associated with an adverse outcome during pregnancy [19-22].

As Illana et al. point out, among the reasons for delaying motherhood in our environment are job instability and job insecurity [23]. Not forgetting that the higher level of education attained by women in recent decades [24,25], together with the difficulty for young people to emancipate themselves from the parental home, are reasons for delaying motherhood [26-29]. This situation is also experienced by foreign women when they enter the labour market, a fact that even leads to the feminisation of certain jobs, a situation that is confirmed in the study, with an average gestational age of up to 36 years [24,25].

In relation to the level of purchasing power in this rural area, women carry out work activities with little training, as it is the partner who carries out their work outside the home $[25,30]$. While it is true that some research shows that foreign women carry out domestic tasks without outside help, this is associated with physical and psychological fatigue due to their long working hours [30-32]. In this sense, it can be affirmed that the social image of the Spanish pregnant woman in Yepes is that of a woman with secondary education, of medium socioeconomic level, economically independent and living with a partner. The social profile of the foreign pregnant woman in Yepes is that of a woman with secondary education, with a lower socio-economic level and economically dependent on her partner.

Several studies show that despite the HE received by the health professional, women with a low socioeconomic status may tend to consume a diet of lower nutritional quality [4,33-35]. These aspects are reflected in the type of delivery and weeks of gestation of the women in our study (38.55 weeks in the foreign group and 40.61 in the Spanish group), and even in the weight of the newborns born by caesarean section (foreigners $2911 \mathrm{~g}$ and Spaniards $3413 \mathrm{~g}$ ).

It is interesting to analyse the variable maternal height as some studies consider this to be a very relevant aspect in the approach to childbirth [36,37], as pregnant women between $1.40 \mathrm{~m}$ and $1.56 \mathrm{~m}$ often tend to have cephalic-pelvic disproportion, give birth by caesarean section and even have low birth weight babies [36-42]. This fact could not be contrasted in our article as all the women in the sample were taller than $1.56 \mathrm{~cm}$.

Since 1985, the WHO has been warning that the caesarean section rate worldwide is very high, and in this sense, the Global Maternal and Perinatal Health Survey and the Multi-country Maternal and Neonatal Health Survey insist on the need to reduce the global caesarean section rate [43-45]. In Spain, this rate has also increased [46,47]. Specifically, in 2018, in the reference hospital of the city of Toledo, caesarean sections accounted for $23.585 \%$ [ 48,49$]$. In our sample, $34.7 \%$ were caesarean deliveries, with the gestational age and weight of the newborn being of note. 
The study warns that pregnant women tend to have an inadequate diet due to excessive consumption of convenience foods and pastries, with a low intake of dairy products, pulses, fruit, vegetables, meat and fish.

The literature shows that the gestational period in all women is a complex process that involves multiple changes in their lives, so it is very important that HE includes a healthy lifestyle [50-53] and diet [54-59]. The study warns that pregnant women tend to have an inadequate diet due to excessive consumption of convenience foods and pastries, with a low intake of dairy products, legumes, fruits, vegetables, meat and fish [54-59].

It is noted that the first trimester of pregnancy is a period of decreased appetite due to the discomfort experienced by some pregnant women in relation to hyperemesis gravidarum [60], a situation reflected in our study. In contrast, the perception of food in the second trimester is characterised by a pleasurable dimension, generally similar to that of the previous gestation [61-63]. The consumption of certain foods increased in both groups of pregnant women due to adequate HE such as eggs, even extrapolating this adequate intake to the different members of the family unit. However, consumption of fish and meat did not increase in the group of foreign women, possibly due to their economic dependence.

In both groups, consumption of convenience foods and cakes was very high, which may be related to cravings during the second trimester. In this regard, studies in pregnant women found that cravings, appetite and taste determine food choices, with pregnant women preferring diets [63-65].

Even so, certain studies emphasise that the risk of preterm birth is lower when the pregnant woman has a higher intake of vegetables, fruits, whole grains, nuts, legumes and seeds, with an exceptionally low intake of red meat, processed and fried foods [66-69].

Several studies indicate that, as a general rule, the dietary behaviour of foreigners in their home country was healthier than in the host country [70-72]. This may be due to changes in dietary behaviour over time, either because of cultural adaptation to the new country or because of the abuse of convenience foods, snacks and industrial pastries [73-78], a situation observed in Yepes' foreign women.

Along the same lines, religion is a positive reinforcement for diet, as women strive to maintain their traditional customs and behaviours [79-83] and this situation was appreciated in our research, as Moroccan, Algerian, Tunisian and Syrian women, through their faith, achieved good results in their biochemical parameters.

\section{Strengths and Limitations}

The results of the sample are limited to the rural environment of the municipality of Yepes, in the province of Toledo in Spain. Therefore, they cannot be generalised to all pregnant women living in Spain, whether native or foreign. The study is also limited by the presence of low-risk pregnancies.

Cultural and linguistic differences could represent a source of bias in the measures used, as the study only collected data from those women who speak Spanish, English and French, so the results cannot be generalised to women who do not speak these languages. It is possible that women with high social status did not participate in the study, as it is quite common for them to follow their pregnancies in private health care. Despite these potential biases, a diverse sample was recruited and maintained throughout the study, which is a strength of the study. Finally, this research was strengthened by prospective data collection, so that pregnancy outcomes were not biased.

\section{Conclusions}

The present study shows that HE has been fundamental for pregnant women in both groups to introduce healthy dietary modifications throughout the three trimesters of pregnancy, improving their health and favouring the correct development and growth of the new life. However, we believe that health promotion from the perspective of human development should take place prior to pregnancy, involving health services and the 
women themselves with the aim of improving the health conditions of pregnant women and their newborns. This would encourage, among other things, a healthier diet during pregnancy and the correct development of pregnancy and childbirth.

Author Contributions: Conceptualization, M.d.D.-A., S.G.-C. and M.T.A.-O.; methodology, M.T.A.-O. and B.Y.-A.; software, M.T.A.-O.; validation, B.M.-G. and B.Y.-A.; investigation, M.d.D.-A.; resources, S.G.-C.; data curation, B.M.-G. and M.I.U.-G.; writing—original draft preparation, M.d.D.-A. and M.T.A.-O.; writing—review and editing, B.Y.-A.; visualization, S.G.-C.; supervision, M.I.U.-G. and B.M.-G.; funding acquisition, S.G.-C. and M.I.U.-G. All authors have read and agreed to the published version of the manuscript.

Funding: Research financed by the European Regional Development Fund (ERDF), Own Research Plan. Resolution of 19/01/2021 (DOCM 27/01/2021), 2021-GRIN-31242. University of Castilla-La Mancha (UCLM).

Institutional Review Board Statement: Clinical Research Ethics Committee of the Toledo Hospital Complex. Castilla-La Mancha Public Health Service (SESCAM). REC no. 125.Informed Consent Statement: Informed consent was obtained from all subjects involved in the study.

Informed Consent Statement: Not applicable.

Acknowledgments: We want to thank the pregnant women and the professionals of the health centers for them.

Conflicts of Interest: The authors declare no conflict of interest.

\author{
Abbreviations \\ WHO World Health Organization \\ HE Health Education \\ SESCAM Servicio de Salud de Castilla-La Mancha
}

\title{
References
}

1. Sánchez, Á. Guía de Alimentación Para Embarazadas; Medicadiet: Madrid, Spain, 2015.

2. Inga Esteban, J.J.I. Prevalencia de Malnutrición Protéico-Energético en Gestantes Mediante Análisis de Albúmina Sérica en el I.N.M.P., en el Periodo Octubre - Noviembre del 2010; Universidad Nacional Mayor de San Marcos: Lima, Perú, 2011.

3. Cereceda Bujaico, M.D.P.; Quintana Salinas, M.R. Consideraciones para una adecuada alimentación durante el embarazo. Rev. Peru. Ginecol. Obstet. 2014, 60, 153-160. [CrossRef]

4. Barretto, L.; Mackinnon, M.J;; Poy, M.S.; Wiedemann, A.; López, L.B. Estado actual del conocimiento sobre el cuidado nutricional de la mujer embarazada. Rev. Esp. Nutr. Hum. Dietética 2014, 18, 226-237. [CrossRef]

5. Minjarez-Corral, M.; Rincón-Gómez, I.; Morales-Chomina, Y.A.; Espinosa-Velasco, M.D.J.; Zárate, A.; Hernández-Valencia, M. Gestational weight gain as a risk factor for developing obstetric complication. Perinatol. Reprod. Hum. 2014, 28, 159-166.

6. Barker, M.; Baird, J.; Tinati, T.; Vogel, C.; Strommer, S.; Rose, T.; Begum, R.; Jarman, M.; Davies, J.; Thompson, S.; et al. Translating Developmental Origins: Improving the Health of Women and Their Children Using a Sustainable Approach to Behaviour Change. Healthcare 2017, 5, 17. [CrossRef] [PubMed]

7. Guía de Práctica Clínica de Atención en el Embarazo y Puerperio Ministerio de Sanidad, Servicios Sociales e Igualdad Agencia de Evaluación de Tecnologías Sanitarias de Andalucía. 2014, pp. 394-404. Available online: https:/ /portal.guiasalud.es/wp-content/uploads/2020 /10/gpc_533_embarazo_aetsa_compl_caduc.pdf (accessed on 21 February 2019).

8. FIGO. International Federation of Gynecology and Obstetrics (FIGO) Launches a Global Framework for Action to Improve the Diagnosis and Care of Women with Gestational Diabetes Mellitus (GDM) and to Improve Adolescent, Preconception and Maternal Nutrition; FIGO: London, UK, 2015.

9. World Health Organization. WHO Recommendations on Antenatal Care for a Positive Pregnancy Experience; World Health Organization: Geneva, Switzerland, 2016.

10. Flores-Quijano, M.E.; Vega-Sanchez, R.; Tolentino-Dolores, M.C.; Lopez-Alarcon, M.G.; Flores-Urrutia, M.C.; Lopez-Olvera, A.D.; Talavera, J.O. Obesity Is Associated with Changes in Iron Nutrition Status and Its Homeostatic Regulation in Pregnancy. Nutrients 2019, 11, 693. [CrossRef]

11. Ministerio de Sanidad, Servicios Sociales e Igualdad. Marco conceptual de los determinantes de las desigualdades sociales en salud. In Fuente: Avanzando Hacia la Equidad; 2015. Available online: https:/ /www.mscbs.gob.es/profesionales/saludPublica/ prevPromocion/promocion/desigualdadSalud/docs/Propuesta_Politicas_Reducir_Desigualdades.pdf (accessed on 12 April 2019). 
12. Solans, A. Alimentación y Mujeres Migrantes en Buenos Aires. Trayectorias de Migración, Políticas Públi-Cas y Comensalidad Familiar. VIII Jornadas de Investigación en Antropología Social Santiago Wallace. [Preimpresión]. 016: [13 p.]. Available online: http://jiassw.filo.uba.ar/sites/jiassw.filo.uba.ar/files/viiijiassw_actas_final_2aed.pdf (accessed on 29 September 2021).

13. Sánchez-Muniz, F.J.; Gesteiro, E.; Espárrago Rodilla, M.; Rodríguez Bernal, B.; Bastida, S. La alimentación de la madre durante el embarazo condiciona el desarrollo pancreático, el estatus hormonal del feto y la concentración de biomarcadores al nacimiento de diabetes mellitus y síndrome metabólico. Nutr. Hosp. 2013, 28, 250-274. [PubMed]

14. Osorio, J.C.; Cruz, E.; Milanés, M.; Ramírez, Y.; Sierra, M.; Cruz, M.; Sanfiel, L. Influence of maternal redox status on birth weight. Reprod. Toxicol. 2011, 31, 35-40. [CrossRef]

15. Weisman, C.S.; Misra, D.P.; Hillemeier, M.M.; Downs, D.S.; Chuang, C.H.; Camacho, F.T.; Dyer, A.-M. Preconception predictors of birth outcomes: Prospective findings from the Central Pennsylvania Women's Health Study. Matern. Child Health J. 2011, 15, 829-835. [CrossRef] [PubMed]

16. Everette, M. Gestational weight and dietary intake during pregnancy: Perspectives of African American women. Matern. Child Health J. 2008, 12, 718-724. [CrossRef]

17. Raghavan, R.; Dreibelbis, C.; Kingshipp, B.L.; Wong, Y.P.; Abrams, B.; Gernand, A.D.; Rasmussen, K.M.; Siega-Riz, A.M.; Stang, J.; Casavale, K.O. Dietary patterns before and during pregnancy and maternal outcomes: A systematic review. Am. J. Clin. Nutr. 2019, 109 (Suppl. 1), 705S-728S. [CrossRef]

18. INE INdE. Proyección de la Población de España 2014-2064; Nota de Prensa: Madrid, Spain, 2014; pp. 1-15.

19. Servicio de Ginecología del HVS; Matronas de Atención Primaria de Toledo; Dirección de Enfermería de la Gerencia de Atención Primaria de Toledo. Embarazo y Puerperio. In Guia de Embarazo; Junta de Comunidades de Castilla-La Mancha: Toledo, Spain, 2009.

20. Niata-Codesal, D. Me Hace Sentir Como si Estuviera en Ecuador. Alimentacion y Sensaciones de Hogar en los Inicios de la Migración Ecuatoriana en Santander. In Alimentación y Migraciones en Iberoamérica; UOC: Barcelona, Spain, 2009; pp. 137-153.

21. Casteleiro, A.; Paz-Zulueta, M.; Paras-Bravo, P.; Ruiz-Azcona, L.; Santibanez, M. Association between advanced maternal age and maternal and neonatal morbidity: A cross-sectional study on a Spanish population. PLoS ONE 2019, 14, e0225074. [CrossRef]

22. Marzo Castillejo, M. Estadisticas sobre demografia, morbimortalidad, encuesta Nacional de salud y recursos sanitarios. JANO 2008, 1693, 29-45.

23. González-Moreno, J.; Juárez-López, J.S.; Rodríguez-Sánchez, J.L. Pregnancy and obesity. Rev. Méd. 2013,4 , $269-275$.

24. Martínez Buján, R. La Reciente Inmigración Latinoamericana a España; Celade: Santiago de Chile, Chile, 2003.

25. Molpeceres Álvarez, L. Situación Laboral de las Mujeres Migrantes en España. In Cuadernos de Relaciones Laborales; ENRED Consultoría: Comillas, Spain, 2012; Volume 30, pp. 91-113.

26. López García, J.; Mariano Juárez, L.; Medina, F.X. Usos y significados contemporáneos de la comida desde la antropología de la alimentación en América Latina y España. Disparidades. Rev. Antropol. 2016, 71, 327-370. [CrossRef]

27. Mills, M.; Rindfuss, R.R.; McDonald, P.; Te Velde, E. Why do people postpone parenthood? Reasons and social policy incentives. Hum. Reprod. Update 2011, 17, 848-860. [CrossRef] [PubMed]

28. Leiva, J.Y.M. (Ed.) Gestión de la Diversidad Cultural en Contextos de Participación Comunitaria; Miradas Educativas Para la Inclusion Social: Barcelona, Spain, 2013.

29. Ríos, M.; Moreno, P.Y.; Vallejo, M. Estudio comparativo entre inmigrantes latinoamericanos y autóctonos de la satisfacción en los ámbitos laboral, familiar, residencial y de pareja. In Actas del I Congreso Internacional Sobre Migraciones en Andalucia; Kressova, F.J.G.C.N., Ed.; Instituto de Migraciones: Granada, Sapin, 2011; pp. 1129-1135.

30. Mestre, R.M.M. (Ed.) Trabajadoras de Cuidado: Las Mujeres de la Ley de Extranjería. In Mujeres en el Camino, El Fenómeno de la Migración Femenina en España; Icaria: Barcelona, Spain, 2005.

31. Andreina, S.-B. Una Propuesta Para la Modificación del Índice de Desarrollo Humano; Revista CEPAL Santiago de Chile: Santiago, Chile, 2014.

32. Maldonado Mera, B.R.; Lara Burbano, G.J.; Maya Carrillo, A.M. La Mujer como motor del desarrollo local: Una experiencia puntual. Rev. San Gregor. 2015, 91-107. [CrossRef]

33. García Calvente, M.D.M.; del Río Lozano, M.; Marcos Marcos, J. Guía de Indicadores Para Medir las Desigualdades de Género en Salud y Sus Determinantes; Escuela Andaluza de Salud Pública (EASP): Sevilla, Spain, 2015.

34. López-Jiménez, S.; Luna-Vega, C.; Tejero-Jiménez, A.; Ruiz-Ferrón, C. Índice de masa corporal, ganancia de peso y patología en el embarazo. Matronas Profesión 2019, 20, 105-111.

35. Leyva Trinidad, D.A.; Pérez Vázquez, A. Pérdida de las raíces culinarias por la transformación en la cultura alimentaria. Rev. Mex. Cienc. Agrícolas 2015, 6, 867-881. [CrossRef]

36. Rendón, M.T.; Apaza, D.H. Crecimiento fetal del recién nacido peruano según su sexo, región geográfica, paridad y talla materna. Ginecol. Y Obstet. Mex. 2008, 76, 512-519.

37. Lascano, P.P.; Miñaca, A.C. Cómo influyen la talla materna y diversos factores en el peso del recién nacido. Bol. Pediatr. 2011, 51, 53-59.

38. Cruz Almaguer, C.C.; Cruz Sánchez, L.; López Menes, M.; González, J.D. Nutrición y embarazo: Algunos aspectos generales para su manejo en la atención primaria de salud. Rev. Habanera Cienc. Méd. 2012, 11, 168-175.

39. Pacora, P.; Ingar, W.; Buzzio, Y.; Reyes, M.; Oliveros, M. Desproprorción fetopélvica en un hospital Lima: Prevalencia, consecuencias, predicción y prevención. Rev. Peru. Ginecol. Obstet. 2007, 53, 193-198. [CrossRef] 
40. Guzmán, V.; García, P.; Liu, H. Talla materna baja como factor de riesgo de cesárea. Rev. Peru. Ginecol. Y Obstet. 2001, 47, 117-120. [CrossRef]

41. Varea, C.; Bernis, C.; González, A.G. Maternal characteristics and temporal trends in birth outcomes: Comparison between Spanish and migrant mothers. Int. Popul. Res. 2012, 2012, 412680. [CrossRef]

42. Roberts, C.L.; Nippita, T.A. International caesarean section rates: The rising tide. Lancet Glob. Health 2015, 3, e241-e242. [CrossRef]

43. Vogel, J.P.; Betrán, A.P.; Vindevoghel, N.; Souza, J.P.; Torloni, M.R.; Zhang, J.; Tunçalp, Ö.; Mori, R.; Morisaki, N.; Ortiz-Panozo, E. Use of the Robson classification to assess caesarean section trends in 21 countries: A secondary analysis of two WHO multicountry surveys. Lancet Glob. Health 2015, 3, e260-e270. [CrossRef]

44. Huang, K.; Yan, S.; Wu, X.; Zhu, P.; Tao, F. Elective caesarean section on maternal request prior to 39 gestational weeks and childhood psychopathology: A birth cohort study in China. BMC Psychiatry 2019, 19, 1-11. [CrossRef] [PubMed]

45. Benlloch-Doménech, C.; Barbé-Villarubia, M.J.; Ribera, J.C. Reflexiones al final de un inicio: Estudio de asociación entre variables sociodemográficas y tipo de parto en la prevención de la violencia obstétrica en España. MUSAS. Rev. Investig. Mujer Salud Sociedad 2019, 4, 98-119.

46. Silverstein, L.M. Guidelines for gender-sensitive disaster management by Asia Pacific Forum on Women, Law and Development: A revolutionary document. Reprod Health Matters. 2008, 16, 153-158. [CrossRef]

47. Addo, O.Y.; Stein, A.D.; Fall, C.H.; Gigante, D.P.; Guntupalli, A.M.; Horta, B.L.; Kuzawa, C.W.; Lee, N.; Norris, S.A.; Prabhakaran, P.; et al. Maternal height and child growth patterns. J. Pediatr. 2013, 163, 549-554. [CrossRef] [PubMed]

48. Wiklund, I.; Edman, G.; Ryding, E.L.; Andolf, E. Expectation and experiences of childbirth in primiparae with caesarean section. BJOG 2008, 115, 324-331. [CrossRef]

49. Juan, J.; Gil, M.M.; Rong, Z.; Zhang, Y.; Yang, H.; Poon, L.C. Effect of coronavirus disease 2019 (COVID-19) on maternal, perinatal and neonatal outcome: Systematic review. Ultrasound Obstet. Gynecol. 2020, 56, 15-27. [CrossRef]

50. Aguilar Cordero, M.; Sánchez López, A.; Rodríguez Blanque, R.; Noack Segovia, J.; Cano, P.; López-Contreras, G.; Mur Villar, N. Actividad física en embarazadas y su influencia en parámetros materno-fetales: Revisión sistemática. Nutr. Hosp. 2014, 30, 719-726. [PubMed]

51. Stephenson, J.; Heslehurst, N.; Hall, J.; Schoenaker, D.A.; Hutchinson, J.; Cade, J.E.; Poston, L.; Barrett, G.; Crozier, S.R.; Barker, M. Before the beginning: Nutrition and lifestyle in the preconception period and its importance for future health. Lancet 2018, 391, 1830-1841. [CrossRef]

52. Hanson, M.; Barker, M.; Dodd, J.M.; Kumanyika, S.; Norris, S.; Steegers, E.; Stephenson, J.; Thangaratinam, S.; Yang, H. Interventions to prevent maternal obesity before conception, during pregnancy, and post partum. Lancet Diabetes Endocrinol. 2017, 5, 65-76. [CrossRef]

53. Ho, A.; Flynn, A.C.; Pasupathy, D. Nutrition in pregnancy. Obstet. Gynaecol. Reprod. Med. 2016, 26, 259-264. [CrossRef]

54. Merchant, K.M.; Kurz, K.M. Women's nutrition through the life cycle: Social and biological vulnerabilities. In The Health of Women; Routledge: New York, NY, USA, 2018; pp. 63-90.

55. Picciano, M.F. Pregnancy and lactation: Physiological adjustments, nutritional requirements and the role of dietary supplements. J. Nutr. 2003, 133, 1997S-2002S. [CrossRef] [PubMed]

56. Morrison, J.L.; Regnault, T.R. Nutrición en el embarazo: Optimización de la dieta materna y adaptaciones fetales al suministro de nutrientes alterado. Nutrientes 2016, 8, 342. [CrossRef] [PubMed]

57. Hambidge, K.M.; Krebs, N.F.; Westcott, J.E.; Garces, A.; Goudar, S.S.; Kodkany, B.S.; Pasha, O.; Tshefu, A.; Bose, C.L.; Figueroa, L. Preconception maternal nutrition: A multi-site randomized controlled trial. BMC Pregnancy Childbirth 2014, 14, 1-16. [CrossRef]

58. Lander, R.L.; Hambidge, K.M.; Westcott, J.E.; Tejeda, G.; Diba, T.S.; Mastiholi, S.C.; Khan, U.S.; Garcés, A.; Figueroa, L.; Tshefu, A. Pregnant women in four low-middle income countries have a high prevalence of inadequate dietary intakes that are improved by dietary diversity. Nutrients 2019, 11, 1560. [CrossRef]

59. Guillemin, F.; Bombardier, C.; Beaton, D. Cross-cultural adaptation of health-related quality of life measures: Literature review and proposed guidelines. J. Clin. Epidemiol. 1993, 46, 1417-1432. [CrossRef]

60. Klimacka-Nawrot, E.; Suchecka, W.; Hartman, M.; Gałazka, A.; Musialik, J.; Petelenz, M.; Błonska-Fajfrowska, B. Changes in food preferences in pregnant women. Wiad. Lek. 2012, 65, 10-14. [PubMed]

61. Cuervo, M.; Sayon-Orea, C.; Santiago, S.; Martínez, J.A. Dietary and health profiles of Spanish women in preconception, pregnancy and lactation. Nutrients 2014, 6, 4434-4451. [CrossRef]

62. Downs, D.S.; Savage, J.S.; Rauff, E.L. Falling short of guidelines? Nutrition and weight gain knowledge in pregnancy. J. Women's Health Care 2014, 184, 2-6. [CrossRef]

63. Ortega Anta, R.M.; Jiménez Ortega, A.I.; Perea Sánchez, J.M.; Lombán, B.N. Desequilibrios nutricionales en la dieta media española; barreras en la mejora. Nutr. Hosp. 2014, 29-35.

64. Correa, L.M.M.; Cadavid, A.D.; Sosa, B.E.P.; Mesa, S.L.R.; López, L.M. Modificacion del aporte de energia y de nutrientes en la dieta de embarazadas que participaron en un programa de complementacion y suplementacion alimentaria. Perspect. Nutr. Hum. 2008, 10, 153-163.

65. Groth, S.W.; Morrison-Beedy, D. Low-income, pregnant, African American women's views on physical activity and diet. J. Midwifery Women's Health 2013, 58, 195-202. [CrossRef]

66. Mesa, S.L.R.; Sosa, B.E.P. Implicaciones del estado nutricional materno en el peso al nacer del neonato. Perspect. Nutr. Hum. 2009, $11,179-186$. 
67. Chen, X.; Zhao, D.; Mao, X.; Xia, Y.; Baker, P.N.; Zhang, H. Maternal Dietary Patterns and Pregnancy Outcome. Nutrients 2016, 8, 351. [CrossRef]

68. Chatzi, L.; Mendez, M.; Garcia, R.; Roumeliotaki, T.; Ibarluzea, J.; Tardón, A.; Amiano, P.; Lertxundi, A.; Iniguez, C.; Vioque, J. Mediterranean diet adherence during pregnancy and fetal growth: INMA (Spain) and RHEA (Greece) mother-child cohort studies. Br. J. Nutr. 2012, 107, 135-145. [CrossRef]

69. World Health Organization. Good Maternal Nutrition: The Best Start in Life; World Health Organization: Geneva, Switzerland, 2016.

70. Cunningham, S.A.; Ruben, J.D.; Narayan, K.V. Health of foreign-born people in the United States: A review. Health Place 2008, 14, 623-635. [CrossRef] [PubMed]

71. Sanou, D.; O’Reilly, E.; Ngnie-Teta, I.; Batal, M.; Mondain, N.; Andrew, C.; Newbold, B.K.; Bourgeault, I.L. Acculturation and nutritional health of immigrants in Canada: A scoping review. J. Immigr. Minority Health 2014, 16, 24-34. [CrossRef] [PubMed]

72. Goulão, B.; Santos, O.; Carmo, I.D. The impact of migration on body weight: A review. Cad. Saúde Pública 2015, 31, 229-245. [CrossRef] [PubMed]

73. Gilbert, P.A.; Khokhar, S. Changing dietary habits of ethnic groups in Europe and implications for health. Nutr. Rev. 2008, 66, 203-215. [CrossRef]

74. Oza-Frank, R.; Narayan, K.V. Effect of length of residence on overweight by region of birth and age at arrival among US immigrants. Public Health Nutr. 2010, 13, 868-875. [CrossRef] [PubMed]

75. Ross, S.E.T.; Larson, N.; Graham, D.J.; Neumark-Sztainer, D. Longitudinal changes in physical activity and sedentary behavior from adolescence to adulthood: Comparing US-born and foreign-born populations. J. Phys. Act. Health 2014, 11, 519-527. [CrossRef]

76. Sánchez-Sicilia, A.A.; de Bustamante Pérez, P.S.; Useros, N.R. Estudio cualitativo de la conducta alimentaria en una población de mujeres embarazadas inmigrantes en el municipio de Fuenlabrada. Nutr. Clin. Dietética Hosp. 2013, 33, 51-60.

77. Rey, A.; Grande, R. El Efecto de las Condiciones de Llegada en la Reproducción de las Mujeres Migrantes. Reis Rev. Española Investig. Sociológicas 2017, 159, 113-134. [CrossRef]

78. Gil, A.; Vioque, J.; Torija, E. Usual diet in Bubis, a rural immigrant population of African origin in Madrid. J. Hum. Nutr. Diet. 2005, 18, 25-32. [CrossRef]

79. Regev-Tobias, H.; Reifen, R.; Endevelt, R.; Havkin, O.; Cohen, E.; Stern, G.; Stark, A. Dietary acculturation and increasing rates of obesity in Ethiopian women living in Israel. Nutrition 2012, 28, 30-34. [CrossRef]

80. Renzaho, A.M.; Gibbons, C.; Swinburn, B.; Jolley, D.; Burns, C. Obesity and undernutrition in sub-Saharan African immigrant and refugee children in Victoria, Australia. Asia Pac. J. Clin. Nutr. 2006, 15, 482-490. [PubMed]

81. Quintanilha, M.; Mayan, M.J.; Thompson, J.; Bell, R.C. Contrasting "back home" and "here": How Northeast African migrant women perceive and experience health during pregnancy and postpartum in Canada. Int. J. Equity Health 2016, 15, 1-8. [CrossRef] [PubMed]

82. Garnweidner, L.M.; Terragni, L.; Pettersen, K.S.; Mosdøl, A. Perceptions of the host country's food culture among female immigrants from Africa and Asia: Aspects relevant for cultural sensitivity in nutrition communication. J. Nutr. Educ. Behav. 2012, 44, 335-342. [CrossRef]

83. Nicolaou, M.; Benjelloun, S.; Stronks, K.; Van Dam, R.; Seidell, J.; Doak, C. Influences on body weight of female Moroccan migrants in the Netherlands: A qualitative study. Health Place 2012, 18, 883-891. [CrossRef] 